\title{
How to Prepare a School Based Disaster Preparedness in Indonesia
}

\author{
Satriya Pranata ${ }^{1, *}$ Sri Widodo ${ }^{2}$ Aric Vranada ${ }^{3}$ Machmudah $^{4}$ Mariyam Mariyam $^{5}$ \\ ${ }^{1-5}$ Faculty of Nursing and Health Sciences Universitas Muhammadiyah Semarang, Indonesia \\ ${ }^{1,3}$ PhD Candidate, National Taipei University of Nursing and Health Sciences, Taiwan \\ *Corresponding author.Email: satriya.pranata@unimus.ac.id
}

\begin{abstract}
Indonesia is located along the Pacific Ring of Fire and close to some natural hazards, including earthquakes, tsunamis, volcanic eruptions, flooding, and droughts. BNPB (the National Agency for Disaster Management) recorded 436 deaths, 1353 mild injuries, 783 serious injuries, and 77,975 houses also, and schools were damaged. It is important to build awareness of disaster and culture of disaster risk reduction. This article provides information about how to build a culture of alertness and safety in schools by developing a network of fellow stakeholders in the field of disaster management in Indonesia. Therefore, a conceptual framework for schools-based disaster preparedness should be provided. Preparation, resources, simulation, and promotion phases for health policy-makers are the important aspects of school-based disaster preparedness in Indonesia. Many countries have successfully implemented a school-based disaster preparedness strategy. The information about this program is expected to build preparedness in the future, as well as prevent the losses of life and property from the future hazardous event.
\end{abstract}

Keywords: Disaster Management, Schools-based disaster preparedness, Preparation, Resources, Simulation, Promotion

\section{INTRODUCTION}

Indonesia, which is located along the ring of fire, is potential to natural hazards such as earthquakes, tsunamis, volcanic eruptions, flooding, and droughts [1]. About 290 significant natural hazards were reported over the last 30 years [2]. Also, Indonesian is located at the meeting points of the earth's tectonic plates where the Eurasian plate in the west and south side, then Philippine sea plate on the east side, [3]. Therefore, this country is geographically vulnerable to natural hazards or disaster such as the earthquake, landslides, and volcanoes, $[4,5]$.

Moreover, climate changes and the growth of the human population make Indonesia more vulnerable to disasters $[6,7]$. It means that the geographical and demographic characteristics have positioned Indonesia into a country with a high level of risk for natural disasters [1]. The major disaster that occurred at Lombok in the latest 2018 recorded 436 deaths, 1353 mild injuries, and 783 serious injuries. Moreover, 77,975 houses and schools were damaged. However, other impacts on psychological, educational, economic, and social areas were not mentioned [2]. It was proven that building awareness and culture regarding disaster are essential among Indonesians.

The government has initiated various efforts to increase risk awareness and safety culture. In 2006, Bappenas (National Development Planning Agency) in cooperation with the Badan Koordinasi Nasional Penanganan Bencana/ BAKORNAS PB (National Coordinating Board for Disaster
Management) supported by United Nations Development Programme (UNDP) formulated the Rencana Aksi Nasional Pengurangan Risiko Bencana/RAN PRB (National Action Plan for Disaster Risk Reduction) 2006-2009, [8]. Moreover, risk reduction activities, as stated in Law No. 24 of 2007 concerning disaster Management, must be included in the education sector in the form of school-based disaster preparedness. It is because education is one of the significant factors in disaster risk reduction activities, [9].

School-based disaster preparedness is crucial for preparing the basic knowledge among Indonesian society [10]. The existence of the school is effective, dynamic, beneficial, and sustainable to present disaster-related education activities as an effort to disseminate education and knowledge about the disaster, [11]. The provision of disaster education in schools has a good impact since the provided information and knowledge about the disaster can be transmitted and conveyed by students to their nearest community [12].

Implementing a school-based disaster preparedness should start by improving the understanding and knowledge of all school components regarding preparedness in school activities, $[10,11,13,14]$. Disaster knowledge possessed by all components of the school plays an important role in the process of self-rescue when a disaster occurs [7]. The more each school component understands the disaster well, the easier it is to take appropriate self-rescue steps, $[11,13]$. School disaster preparedness is aimed to build school capacity 
to deal with disaster through knowledge and attitude reinforcement, school policies, emergency response plans, school early warning systems, and mobilization resources based on existing school capacities, [15]. Preparedness planning in schools must be supported by the standard operating procedure as planned by the school about what, who, when, where, and how the procedures must be carried out in disaster management both before, during, and after a disaster occurs [8]. The procedure (permanent procedure) is made and arranged based on mutual agreement between all the school components. Moreover, the regular simulation must also be applied to make the knowledge provided is ingrained for each trainee, so it is not difficult to be applied between the daily routine activities, $[7,8,12]$.

Besides, to provide knowledge and training on the disaster, disaster mitigation is one of the efforts taken to reduce disaster risk $[6,16]$. This activity is applied through physical and awareness development, also capacity building to deal with natural disasters [12]. Disaster mitigation aims to minimize the risks and provide a sense of security in the school. It is increasing the capacity of school institutions and individuals to create safer learning places for students, teachers, other school personnel, and also communities around the school $[6,12,16]$. Besides, it is also expected to make a meaningful contribution to the stakeholders or government regarding policy related to disaster mitigation activities and school-based disaster preparedness for disaster.

\section{PURPOSE}

This article provides information about how to build alertness and safety culture in schools, then developing a network of fellow stakeholders in the field of disaster management in Indonesia.

\section{DEFINITIONS AND THEORIES OF DISASTERS}

A disaster does not happen by itself. Disasters had occurred long ago before humans knew the science of disasters. The understanding perspectives of disasters are constantly changing from time to time. The different perspectives on disaster initiate new theories about the disaster depends on the level of education and understanding of a person or community.

A theory mentions that a will oppose God's will brings disaster. So, a disaster is a curse or wrath from God due to human activity that is against God's will. Based on this theory, disaster cannot be avoided under God's demand [16]. The other definition explains that a disaster is a natural event caused by human error during the treatment of natural resources. Disaster is a result of natural resources exploitation, which leads to unbalanced nature conditions [16]. Besides, a disaster appears from the interrelations between nature and human elements. The various theories provide us a hint that disasters always involve the main elements, which are the universe, human activity, and the provisions of God [17].

According to Law No.24 of 2007 related to disaster management, disasters are "events or series of events that threaten people's lives and livelihoods caused by natural and or non-natural and human factors. Further, it results in human casualties, environmental damage, property losses, psychological impacts, and the inability of the community to access its resources." [9].

From the definition of disaster above, it can be concluded that a disaster is an event that is natural, human-made, or a combination of the two, causing devastating effects on life. In that event, the elements directly related or affected must respond by taking extraordinary actions to adjust and further restore the conditions to their original state or even better.

\section{TYPE OF COMMON DISASTER IN INDONESIA}

After the text edit has been completed, the paper is ready for the template. Duplicate the template file by using the Save As command, and use the naming convention prescribed by your conference for the name of your paper. In this newly created file, highlight all of the contents and import your prepared text file. You are now ready to style your paper; use the scroll down window on the left of the MS Word Formatting toolbar.

\subsection{Flood}

According to the Bapennas, a flood is a condition of which an overflow of water channels, and most of the water floods. Floods are the most common natural disasters [8]. There are two types of floods, namely flash floods (shipment) and tidal flooding $[2,8]$. The floods mainly caused by long and heavy rain, poor waste management, failed urban planning, the lessening of water catchment areas or green lanes that are pushed by settlements and industry, also the reduced number of plants or trees.

\subsection{Tsunami}

The term tsunami is originated from Japan. Tsu means harbor, Nami means sea waves. A tsunami mainly used as a wave that occurs in coastal areas. Tsunamis are defined as a series of sea waves that strike coastal and land areas due to geological events on the seabed, such as earthquakes, volcanic eruptions, and landslides on the seabed, [8]. Tsunami in Indonesia, which were caused by earthquakes on the seabed, occurred at Banyuwangi in 1994, Biak in 1996, and NAD in 2004. Besides, the tsunami from a volcanic eruption on the seabed happened during the Krakatoa eruption in 1883. 


\subsection{Landslide}

Landslides are usually related to problematic soil density or unstable ground on slopes. The problem of soil density and unstable ground on slopes mainly worsen by excessive tree cutting in some areas of Indonesia. Landslides occur around residential areas are at high risk of causing damage and loss of life. A data in a certain study states that 247 cases of a landslide occurred in Indonesia [13]. Heavy rain and floods, seismic activity, erosion from the ocean and rivers as well as vegetation were also affecting and giving a huge impact on soil compilation, $[2,8,12]$.

\subsection{Earthquake}

Earthquakes are severe shocks that occur on the surface of the earth [18]. These shocks are caused by movements in the outer layers of earth. Usually, an earthquake occurs. Two blocks of the earth suddenly slip past one another. The surface where they slip is called the fault or fault plane. Earthquakes are caused by movements of the crust of the earth's plates [19]. When the earthquake point occurs below the earth's surface is called the hypocentre, the earthquake point above the earth's surface is called the epicenter [8]. Earthquakes can be classified as tectonic, volcanic, rock, artificial, and impact earthquakes. Among others, $95 \%$ of earthquake events in Indonesia occur in the form of tectonic earthquakes, $[2,8,18]$. The numbers of earthquakes that occurred at Lombok during 2018 were 1973 earthquakes [2].

\subsection{Volcano}

A volcanic eruption is one of the natural disasters that often appear around Indonesia. The large number of volcanoes scattered along the large islands like Sumatra, Java, Bali, Nusa Tenggara, Maluku, and Sulawesi worsened the situation. One of the biggest volcanic eruptions was occurred in the province of Jogjakarta in 2010 and killed 275 people [8].

\section{CLEARING THE CONCEPT OF A SCHOOL BASED PREPAREDNESS}

According to Law Number 24 the Year 2007 regarding Disaster Management, Preparedness is "a series of activities carried out to anticipate disasters through organization and appropriate and efficient steps." This includes the development/improvement of overall preparedness strategies, policies, institutional structures, warnings, and predictability, as well as plans that determine measures that are suitable to help communities at risk of saving their lives and assets by alerting to disasters and taking appropriate action in overcome the imminent threat or true disaster, [9]. Moreover, preparedness is preparing knowledge and capacity by government, organization, or individual, which focuses on emergency response and communities for anticipating, responding, and recovering from the disaster condition [8].
Disaster Preparing Schools are schools that can manage disaster risks in their environment. This capability is measured by the provided disaster management plan (before, during and after a disaster), the availability of logistics, security and comfort in the educational environment, infrastructure, and emergency systems, which are supported by the knowledge and ability of preparedness, permanent procedures and early warning systems. This ability could be achieved through regular simulations with the cooperation of various related components by institutionalizing the policies of the educational institution. It is aimed to transform the knowledge and practice of disaster management as well as disaster risk reduction to all school members as the constituents of the educational institution.

The preparedness of school for disasters is the representation of the National Action Plan for Disaster Risk Reduction, which supports disaster preparedness for effective responses at all levels of society, to build a culture of safety and resilience at all levels. Thus, the concept of a school disaster preparedness does not only focus on the element of preparedness but also the efforts to develop innovative knowledge and achieve a culture of safety, security, and resilience for all school residents to disaster. In conclusion, based on this concept, a school disaster preparedness has two main elements. The first is a safe learning environment, and the second is school community preparedness $[2,8,18,20]$.

\section{PARAMETER OF SCHOOL BASED DISASTER PREPAREDNESS}

Parameters, indicators, and verification about how to measure the development of school-based disaster preparedness need to be determined. A parameter is a minimum standard and level that is needed to be achieved. Further, the indicator is the specified standard to be achieved. This indicator provides an overview of the impact or results of a program, process, and methods used. Indicators can be qualitative or quantitative in nature. Parameter of school preparedness consists of four factors, which are attitude and action, school Policy, preparedness planning, and resource mobilization $[2,8,18,20]$.

\subsection{Attitude and Action}

Building the capacity regarding perception, knowledge, and skill of the school elements community, whether individually and collectively, to be prepared for disasters promptly and efficiently are the basis in attitude and action parameter. Therefore, students and other school element communities are the targets.

\subsection{School Policy}

School policy is a formally binding decision made by schools on the matters needed to support the implementation of School-based Disaster Preparedness. Practically, the school's policy shall be the foundation, guideline, and 
direction for the implementation of School-based Disaster Preparedness related activities.

\subsection{Preparedness Planning}

Preparedness planning is done to ensure that fast and efficient actions can be taken when a disaster occurs. The planning should be adjustable or considerable to local disaster management systems or environmental conditions. The Standard Operational Procedure, alternative plans, accurate early warning system that takes into account the local context, and other supporting preparedness documents can be provided.

\subsection{Resources Mobilization}

Schools should prepare human resources, facilities, infrastructure, and financial support for disaster management to ensure that school disaster preparedness can be well implemented. The size of the resource arrangement is designed according to the school's capacity and stakeholder's policy. Every decision-making process is open, so anyone can take part in thoughts and ideas.

The four parameters' elements cannot stand alone, as the elements are closely related to one another. Measurements obtained from related schools will determine the level of school resilience to certain hazards. Practically, school readiness should be integrated with the efforts of the local government, other stakeholders, and the community around the school.

\section{DEVELOPING A CONCEPTUAL FRAMEWORK FOR SCHOOL BASED PREPAREDNESS IN INDONESIA BASED ON A PARAMETER OF FOUR FACTORS}

\begin{tabular}{|c|c|c|c|}
\hline \multicolumn{4}{|c|}{ Preparation } \\
\hline \multirow{3}{*}{$\begin{array}{l}\text { Discussion } \\
\text { with } \\
\text { headmaster } \\
\text { and teachers } \\
\text { to make the } \\
\text { school's } \\
\text { policy }\end{array}$} & \multicolumn{3}{|l|}{ Resources } \\
\hline & \multirow{3}{*}{\begin{tabular}{|l|} 
Prepare \\
human \\
resource, \\
facility, \\
infrastructure \\
and financial \\
support for \\
disaster \\
management \\
to ensure the \\
school's \\
disaster \\
preparedness
\end{tabular}} & \multicolumn{2}{|c|}{ Simulation } \\
\hline & & \multirow{2}{*}{\begin{tabular}{|l|} 
The \\
simulation \\
is done \\
twice in a \\
year, at \\
the end of \\
semester.
\end{tabular}} & $\begin{array}{l}\begin{array}{l}\text { Promotion for } \\
\text { health policy }\end{array} \\
\end{array}$ \\
\hline $\begin{array}{l}\text { Preparing } \\
\text { Standard } \\
\text { Operating } \\
\text { Procedure/SO } \\
\text { P and early } \\
\text { warning } \\
\text { system }\end{array}$ & & & \multirow{4}{*}{$\begin{array}{l}\text { collaborate with } \\
\text { journalis or local } \\
\text { newspapers to } \\
\text { report the progress } \\
\text { of activities } \\
\text { countinuesly. } \\
\text { hopefully from } \\
\text { these activities, } \\
\text { other schools will } \\
\text { participate and start } \\
\text { to build a disaster } \\
\text { response system. } \\
\text { Therefore, the } \\
\text { government starts to } \\
\text { aware and inspired } \\
\text { to launch this } \\
\text { activity in the } \\
\text { curriculum, as well } \\
\text { as provide the } \\
\text { sustainable funding. } \\
\text { besides, government } \\
\text { is expected to } \\
\text { willingly build an } \\
\text { earthquake-resistant } \\
\text { school in in } \\
\text { earthquake-prone } \\
\text { areas }\end{array}$} \\
\hline $\begin{array}{l}\text { Planning } \\
\text { (emergency }\end{array}$ & $\begin{array}{l}\text { to measure } \\
\text { disaster }\end{array}$ & & \\
\hline $\begin{array}{l}\text { access, } \\
\text { evacuation } \\
\text { routes), } \\
\text { training } \\
\text { (emergency } \\
\text { teams, } \\
\text { practice drills } \\
\text { for students }\end{array}$ & $\begin{array}{l}\text { preparedness } \\
\text { in school, and } \\
\text { each } \\
\text { parameter } \\
\text { cannot stand- } \\
\text { alone, but } \\
\text { should be } \\
\text { linked to one }\end{array}$ & & \\
\hline $\begin{array}{l}\text { element of } \\
\text { school) and } \\
\text { supply } \\
\text { (providing } \\
\text { emergency } \\
\text { response } \\
\text { equipment) }\end{array}$ & $\begin{array}{l}\text { another } \\
\text { (government, } \\
\text { communities } \\
\text { around the } \\
\text { school and } \\
\text { relevant } \\
\text { stakeholders). }\end{array}$ & & \\
\hline
\end{tabular}

Figure 1 Conceptual framework for school based disaster preparedness in Indonesia

\subsection{Preparation Phase}

This is an important stage to discuss the school-based preparedness with policy-makers such as headmaster and teachers. The discussion will be aimed to discuss the planning and preparation of standard operating procedures and warning systems that are appropriate for the school. The adjustments of the program must be made based on the school's characteristics, values, and resources. A discussion to reach an agreement among the school elements will determine the success of the program.

After the entire elements agree on the implementation of the program, and appropriate standard operating procedures have been established, then planning the formation of emergency access, evacuation routes, what training will be done to increase the capacity of all elements in the school related to knowledge and skills could be discussed regularly with all elements of policy-makers in schools. It should be noted that disaster management in a certain location will be different from other locations, as well as the needs in handling 
it. When all program preparation and planning have been formulated, the next stage can be carried out.

\subsection{Resources Phase}

Things that need to be prepared in this stage are human resources, facilities that support programs, infrastructure, and disaster management financial support to ensure school disaster preparedness. Training on each resource is very necessary so that all teams will be ready when a disaster occurs. The communication team functions as a connector of information into electronic and printed media so that information can be easily accessed. The audit team is also an important element to ensure all programs run as planned. The core team includes the evacuation team during a disaster, the medical team, transportation, security, public relations, and technical elements. Preparing the evacuation equipment, tools, and medical materials for wound care or basic life support can be completed at this stage. Besides, funds to support the program can be included in the school operational assistance budget from the central or local government. Moreover, assessing the area around the school, especially primary health facilities to be used as an evacuation area, is also needs to be observed before the program is conducted.

\subsection{Simulation Phase}

Simulation activities can be carried out routinely by the school at the end of every semester or at the beginning of the semester. The time of the simulation can be determined according to the agreement between the schools. The simulation activity can be increasing the skill for school disaster preparedness. The more often an activity is carried out, the culture of school-based preparedness is increasingly formed. This way, this program might be successful in the future. When the simulation well implemented, all children in a school can spread the information to their community. This is good to spread information to the wider community.

\subsection{Promotion Phase}

Promotional activities can be systematically carried out through collaborative efforts with journalists or local newspapers to report the progress of activities continuously. Hopefully, from these activities, other schools will participate and start to build their disaster response system. Furthermore, the promotion is expected to raise the government's awareness and further stimulate them to officially launch this activity in the curriculum and provide sustainable funding to build an earthquake-resistant school around earthquake-prone areas.

\section{SWOT ANALYSIS FOR SCHOOL BASED DISASTER PREPAREDNESS}

\subsection{Strength}

8.1.1 Already supported by legislation law in Indonesia

8.1.2 There are a lot of local disaster training institutes that can facilitate the training process
8.1.3 Improve student knowledge, then students can also spread the information to their families at home

\subsection{Weakness}

Funds are needed to procure adequate disaster equipment in schools and large funds are needed for the construction of anti-disaster school buildings

\subsection{Opportunities}

8.3.1 The equipment procurement activity and schoolbased disaster preparedness program can be included in the school grants proposal from the central and regional governments

8.3.2 The central government budget for education funding is very big. The fund reaches $20 \%$ of the state budget

8.3.3 Local disaster training institutes provide free annual training services

8.3.4 Many countries have successfully implemented a school-based disaster preparedness strategy, and finally, from this program, the loss of life and material from damage caused by disasters could be reduced

\subsection{Threats}

8.4.1 Advanced technology is needed in disaster mitigation, such as automatic alerts to give notification about the risk of disaster

8.4.2 School-based disaster preparedness for the high risk disaster is not in line with local government programs that have not yet prioritized disaster preparedness

\section{CONCLUSION}

Preparation, resources, simulation, and promotion stages for health policy-makers are the important aspects of schoolbased disaster preparedness in Indonesia. An activity to start the program is building early warning systems in school, providing evacuation routes, emergency equipment, training, and simulation of disaster continuously. The problem found in disaster preparedness in Indonesia was the interventions that were only contained in regulations and laws, but there was no real action taken by the government. By directly implementing the intervention, it is expected that the culture of disaster management will be improved in the future. Besides, the school will be the right place to start the disaster preparedness culture. The best strategy to build a culture of alertness and safety in schools is to include disaster preparedness into the learning curriculum in the classroom. Also, actively conducting simulations at the end of the semester will make students familiar with strategic steps that must be taken when a disaster occurs. The other important thing to be done is considering building the earthquakeresistant school buildings (mitigation), especially in schools around the volcano or earthquake-prone area. 


\section{AUTHORS' CONTRIBUTIONS}

Author 1: Satriya Pranata

ORCID ID Author 1 0000-0002-2026-8931

Author 2: Sri Widodo

Author 3: Aric Vranada

Author 4: Machmudah

Author 5: Mariyam Mariyam

\section{ACKNOWLEDGMENTS}

Thank you to Technical Unit of Foreign Languages Universitas Muhammadiyah Semarang those who have helped in translating this study.

\section{REFERENCES}

[1] Priester L De. An approach to the profile of disaster risk of Indonesia. Emerg Disaster Reports. 2016;3(2):66.

[2] BNPB. Data dan Informasi Bencana Indonesia, BNPB, < http://dibi.bnpb.go.id/ > (diakses 1 Desember 2019). 2018;

[3] Irsyam M, Asrurifak M, Ridwan M, Aldiamar F, Sengara IW, Widiyantoro S, et al. Geotechnical Predictions and Practice in Dealing with Geohazards. 2013;25(April):33-46. Available from: http://link.springer.com/10.1007/978-94-007-5675-5

[4] Kementrian Kesehatan RI. Riset Kesehatan Dasar (RISKESDAS) 2018. Jakarta: Balitbang Kemkes. 2018;

[5] Kementerian Kesehatan RI. Riset Kesehatan Dasar (RISKESDAS) 2013. Jakarta: Balitbang Kemkes. 2013;

[6] Idris F. Pre-conference Seminar Disaster MedicineEpidemic Disease, Earthquake, Tsunami and Nuclear Disaster The Natural Disaster Related to Health Problem: Indonesia experience. 2012;55(1):2012. Available from: https://www.med.or.jp/english/journal/pdf/2012_01/022 .pdf

[7] KPB. Kerangka Kerja SSB, Jakarta: Konsorsium Pendidikan Bencana. 2011;

[8] Bapennas. bappenas.go.id. Diakses 1 Desember 2019. 2006;

[9] Undang-undangRI. No.24 tahun 2007. Penanggulangan Bencana. Jakarta. 2007;

[10] Sari AL. School in Earthquake Threat: School Based Disaster Preparedness Model in. 2019;(February).

[11] Fathoni M, Yusuf A, Christrijogo Sumartono W. The relationship of the role of teachers in the implemented curriculum of school-based disaster preparedness in vulnerability in school teachers with disabilities in Malang city, Indonesia. Indian J Public Heal Res Dev. 2019;10(8):2762.

[12] Dhiroh. Studi Komparasi Tingkat Kesiapsiagaan Komunitas Sekolah Siaga Bencana dengan Sekolah Non Siaga Bencana dalam Mengantisipasi Ancaman gempabumi dan Tsunami di Kecamatan Kretek Kabupaten Bantul, Tesis: magister Manajemen bencana Universiats Gadjah Mada. 2014;

[13] Rokhmah D, Khoiron K, Burlakovs J. Knowledge, atttitude, and action of community in disaster preparedness at the slope of Semeru Mountain, Indonesia. Ann Trop Med Public Heal. 2020;23(3):3443.

[14] Amri A, Bird DK, Ronan K, Haynes K, Towers B. Disaster risk reduction education in Indonesia: Challenges and recommendations for scaling up. Nat Hazards Earth Syst Sci. 2017;17(4):595-612.
[15] Pascapurnama DN, Murakami A, Chagan-Yasutan $\mathrm{H}$ Hattori T, Sasaki H, Egawa S. Integrated health education in disaster risk reduction: Lesson learned from disease outbreak following natural disasters in Indonesia. Int J Disaster Risk Reduct [Internet]. 2018;29(March 2017):94-102. Available from: https://doi.org/10.1016/j.ijdrr.2017.07.013

[16] Lindell M. Orgins of disaster studies. Sociopedia. 2011;1-18.

[17] Briones F, Vachon R, Glantz M. Local responses to disasters: recent lessons from zero-order responders. Disaster Prev Manag An Int J. 2019;28(1):119-25.

[18] Sanderson D, Sharma A, Kennedy J, Burnell J. Lost In Transition : Principles, Practice And Lessons From Haiti for Urban Post-Disaster Shelter Recovery Programs 1 . Introduction When the 7.8 ( on the Richter scale) earthquake struck Haiti on January 12th 2010 , it hit a country that was already i. 2014;6(2):131-51.

[19] Fernandez MG, Kienberger S, Spiekermann R, Briones F, Norton J, Nussbaum R. Prepared for the Global Assessment Report on Disaster Risk Reduction 2015 ENABLING KNOWLEDGE FOR DISASTER RISK REDUCTION AND ITS INTEGRATION Table of Contents. 2015;(February 2014).

[20] ISDR. System Thematic Cluster/Platform on Knowledge and Education, "Let Our Children Teach Us! A Review of the Role of Education and Knowledge in Disaster Risk Reduction." 2006; 